\title{
On the Performance of KiwiSaver Funds
}

\author{
Bart Frijns* \\ Alireza Tourani-Rad \\ Auckland Centre for Financial Research \\ $\&$ \\ Department of Finance \\ Faculty of Business and Law \\ Auckland University of Technology \\ Auckland, New Zealand
}

*Corresponding author. Auckland Centre for Financial Research and Department of Finance, Auckland University of Technology, Private Bag 92006, 1142 Auckland, New Zealand. Tel. +64 99219999 (ext. 5706); fax.+64 9921 9940; Email: bfrijns@aut.ac.nz. 


\title{
On the Performance of KiwiSaver Funds
}

\begin{abstract}
This study investigates three issues: (1) the replicability of KiwiSaver Balanced (and other intermediate) funds based on a combination of Conservative and Growth funds offered by the same provider; (2) the risk-adjusted performance of the KiwiSaver Growth funds; (3) the market timing skill of KiwiSaver fund managers. We find that for the majority of fund providers, Moderate/Balanced funds are linear combinations of the Conservative and Growth funds with some mispricing between the fees of the actual fund and the reconstructed fund. We further report substantial variation in the amount of risk-taking, and local and international stock market exposure of KiwiSaver Growth funds, making it meaningless to compare these funds simply based on their returns. Using risk-adjusted performance metrics, we observe there is no evidence of systematic outperformance of KiwiSaver Growth funds, and in several cases there is evidence of systematic underperformance. Furthermore there is no sign of market timing skill by KiwiSaver fund managers.
\end{abstract}

Keywords: KiwiSaver, Mutual Funds, Performance Measurement 


\section{Introduction}

The KiwiSaver scheme, predominantly a work-based, voluntary pension system, was introduced on July 1, 2007 in New Zealand. KiwiSaver is a subsidised, defined contribution investment scheme, with the contribution rate currently set at $6 \%$ that is divided equally between the employee and employer. There are further some marginal tax credits for employees. ${ }^{1}$

KiwiSaver funds have come to play an important role in the New Zealand financial landscape in recent years. Since the scheme's inception, investors have gradually realised the importance of investing in KiwiSaver. As of the middle of 2013, assets in KiwiSaver funds exceeded NZ\$15 billion with more than 2.1 million investors. One of the main aims of the New Zealand government when introducing the KiwiSaver scheme was to increase long-term savings of the public and encourage them to provide for better retirement, which, to certain extent, has been met. ${ }^{2}$

To date, there has been very limited academic research on various aspects of KiwiSaver pension scheme, KiwiSaver fund providers and KiwiSaver investors. The main reason is undeniably the young age of this particular fund industry and the lack of long-term data. There are, however, a couple of recent studies that examine several relevant issues. Thomas and Matthews (2013) investigate the determinants of fund

\footnotetext{
${ }^{1}$ Details of KiwiSaver are available at http://www.kiwisaver.govt.nz.

${ }^{2}$ In New Zealand, there is evidence of negative savings among certain segments of society, with youth saving the least (Scobie and Henderson, 2009). Additionally, at the time of the introduction of KiwiSaver, less than 30 per cent of the active labour force was covered by some sort of retirement plan (Kritzer, 2007). The question of sufficient wealth accumulation and the adequacy of the current contribution rate have been investigated in a recent paper by MacDonald, Bianchi and Drew (2012). The authors, applying stochastic simulation analysis, find that the current rate of $6 \%$ is far too low to ensure New Zealanders to have sufficient savings in the long term.
} 
and member flows among KiwiSaver funds. The authors find that, on average, there is a positive relation between performance and both types of flow. However, they also observe a positive relation between performance and outflow that could not be explained. Thomas and Matthews further find inconclusive results when investigating the influence of the size of fund, and number of investors, on fund flows.

In another paper, Zhang (2013), using a unique proprietary data set of 405,107 individual KiwiSaver accounts, investigates the impact that financial advice has on the asset allocation decision of investors. Her findings show that women, older investors and investors with relatively higher levels of wealth appear to obtain financial advice more than others. Second, those investors who receive advice hold riskier assets in their portfolios, less cash and bonds, and more property and equity. Finally, Zhang reports that differences in the performance of the two groups, advised and non-advised investors, is marginal over the 5 year period she examines.

Academic studies on various characteristics of mutual funds, and especially their performance, are abundant ${ }^{3}$. Based on the extant literature, we can assert, in a nutshell, that most mutual funds underperform their respective market index (Fama and French, 2008) and there should be no premium paid for active fund management (Malkiel, 1995; Carhart, 1997). There is further strong evidence that fund performance deteriorates with fund size (Chen, Hong, Huang, and Kubik, 2004) and fees (Gil-Bazo and Ruiz-Verdu, 2009). There are, however, some studies that find that fund managers exhibit some skills. For example, there is certain evidence of short-term persistence in funds' performance (Hendricks, Patel, and Zekhauser, 1993) and that

\footnotetext{
${ }^{3}$ For an exhaustive analysis of various aspects of New Zealand mutual fund performance, please see Bauer, et al (2006).
} 
money flows to past good performers (Del Guerico and Tkac, 2002). Investors are also able to display some fund selection ability as they tend to invest in funds with successive good performance (Zheng, 1999). Although some of the issues raised in the above mentioned studies have been investigated in the context of KiwiSaver, to our knowledge, our paper is the first to examine the performance of KiwiSaver funds.

In this paper, we contribute mainly to two strands of research. First, we investigate the issue of replicability of funds, using KiwiSaver fund family. The question of interest here is to see whether we can replicate a fund that has the same level of risk and return as an existing fund but lower level of fees, which in turn translates into higher returns. Second, we investigate the risk-adjusted performance of KiwiSaver Growth funds as well as their mangers' market timing skills. The sample for our analysis consists of all actively traded growth/equity funds over the period September 2007 April 2013. ${ }^{4}$ We use the Fama-French (1992) and Carhart (1997) multi-factor models to measure risk-adjusted performance, in addition to the traditional market model. We further explore the exposure of these funds to New Zealand and Australian equity market, respectively. Based on anecdotal evidence, and we confirm this empirically, most New Zealand fund managers have their asset allocation concentrated in these two markets. In the final section of our paper, we investigate the market timing ability of KiwiSaver fund managers.

\footnotetext{
${ }^{4}$ There are not a vast variety of funds available to investors. Most fund providers offer four to five categories. For example, BNZ offers: Cash, Conservative, Moderate, Balanced, Growth Funds. These investment funds, to varying degrees based on their risk exposure, then invest in cash, domestic bonds, international bonds, domestic equity, international equity, and property. We have chosen to concentrate only on Growth or Equity funds as they should be mainly investing in equities nationally and internationally. The models applied in our paper are suitable for such funds and cannot be applied indiscriminately to other multi assets funds.
} 
Our findings indicate that, for the majority of fund providers, our synthetic "moderate and balanced funds" are linear combinations of the conservative and growth funds that the KiwiSaver providers offer. We observe that investors should be able, in various instances, to combine the existing funds to replicate a moderate or balanced fund with lower transaction costs. On the whole, we find no evidence that equity/growth KiwiSaver funds outperform based on the various benchmark models we employ, and in some cases we document significant underperformance. Finally, the KiwiSaver fund managers do not exhibit any skills to time their respective market, and in some cases we report significant negative market timing skills.

The rest of this paper proceeds as follows. Section 2 details the methodologies used in this paper. Section 3 describes our data and the selection of our sample. Section 4 presents the empirical results and Section 5 concludes.

\section{Methodology}

We aim to investigate the performance and behaviour of KiwiSaver funds. This analysis consists of three steps. First, we examine the replicability of KiwiSaver funds based on their Conservative and Growth strategies. Second, we examine the risk adjusted performance of the KiwiSaver growth funds, i.e. those that have the greatest exposure to equity investments. Finally, we assess market timing skills of fund managers. 


\subsection{Constrained OLS - Fund Replication}

The first step in our analysis is the examination of whether funds can be replicated within a particular KiwiSaver fund provider. Specifically, we address the question of whether, say, a Balanced fund, or Moderate fund, is a linear combination of a Conservative and Growth fund. To examine this issue, we rely on a constrained OLS methodology that allows estimation a relationship between variables, while imposing constraints on the coefficients that are being estimated. Specifically, we estimate the following model:

$$
r_{i t}=\beta_{1} r_{\text {cons }, t}+\beta_{2} r_{\text {growtht }}+\varepsilon_{t}
$$

This regression imposes the following constraints. First, we constrain the constant in the regression to be zero. Second, we constrain coefficients, $\beta_{1}$ and $\beta_{2}$, to be greater than zero. Third, we add the constraint that the sum of the coefficients is equal to one (i.e. $\beta_{1}+\beta_{2}=1$ ). These restrictions imply that the coefficients, $\beta_{1}+\beta_{2}$, can essentially be interpreted as allocations, or weights, that need to be put on the respective KiwiSaver funds.

To determine whether the allocations in two funds lead to a good replication of the fund in question (e.g., whether a Balanced fund can be constructed out of a Conservative and a Growth fund), we perform a second regression to assess the fit of the replicated fund on the actual fund. Specifically, we regress

$$
\hat{r}_{i t}=\alpha+\beta r_{i t}+\varepsilon_{t},
$$


where $\hat{r}_{i t}$ is the return of the replicated portfolio, and $r_{i t}$ is the return of the actual portfolio. If the replicated portfolio fits the actual portfolio perfectly, then we would expect $\alpha=0$ and $\beta=1$. Whether the replicated portfolio fits the actual portfolio can be assessed through a joint test (F-test) on $\alpha$ and $\beta$ in Equation (2). In addition, if the replicated portfolio fits the actual portfolio well, we would expect a very high $R^{2}$ for this regression.

Note that regressions such as Equation (2) and joint test on the coefficients are commonly used in the financial forecasting literature, where a forecasted value is assessed against the actual realization, and the coefficients and $R^{2}$ are used to assess the forecasting performance of the specific forecaster (see e.g. Andersen et al., 2003).

\subsection{Performance Analysis}

The second step in the analysis of KiwiSaver funds is to analyse the performance of the KiwiSaver funds. This analysis will only be conducted for Growth/Equity funds, as these funds invest most heavily into equity, and the performance measurement literature on equity funds is most developed. In first instance, we assess performance by comparing the performance of funds relative to the New Zealand and Australian stock markets, and second by examining performance in a global context.

The first model we consider is a comparison of the performance of each "growth" fund with the NZX50 and ASX200 market indices. We run the following regression:

$$
R_{t}=\alpha+\beta_{1} N Z X_{t}+\beta_{2} A S X_{t}+\varepsilon_{t},
$$


where $R_{t}$ is the return on a specific fund in excess of the risk-free rate (the 90-day bank bill rate), $N Z X_{t}$ is the return on the NZX 50 index in excess of the risk-free rate, and $A S X_{t}$ is the return on the ASX 200 index (in NZ dollar) in excess of the risk-free rate. The coefficients $\beta_{1}$ and $\beta_{2}$ capture the exposures of the fund relative to the NZX50 and ASX 200 index, respectively, and $\alpha$ will capture the out- or underperformance relative to the two market indices.

Next, we compare each fund to a global equity portfolio and perform a global CAPM regression of the form,

$$
R_{t}=\alpha+\beta R M R F_{t}+\varepsilon_{t}
$$

where $R_{t}$ is the return on a specific fund in excess of the risk-free rate (the 90-day bank bill rate) and $R M R F_{t}$ is the return on the global market portfolio (in NZ dollar) in excess of the risk-free rate. In this regression, $\beta$ captures the exposure of the fund to the global market index, and $\alpha$ captures the out- or underperformance relative to the global market index.

The model in Equation (4) assumes that only market risk is priced. However, in addition to market risk, there are other well-established factors that are known to affect the cross-section of stock returns, and therefore the performance of mutual funds. First, Banz (1981) shows that size has an important role in explaining differences in the cross-section of stock returns. Second, Statman (1980) and Rosenberg et al. (1985) show that book-to-market values have an important role in explaining the cross-section of stock returns. Fama and French (1992) evaluate the 
importance of these two factors in explaining the cross-section of stock returns and find that, on average, small firms outperform large firms, and value stocks (firms with high book-to-market values) outperform growth stocks (firms with low book-tomarket values). Given that these two effects are observed persistently over time throughout the cross-section of stock returns, and that these are known strategies for generating "outperformance", we need to control for them when assessing the performance of mutual funds and in this case KiwiSaver Growth funds. We therefore augment the CAPM with these factors and estimate the so-called Fama and French (1993) 3-factor model:

$$
R_{t}=\alpha+\beta R M R F_{t}+\gamma_{1} S M B_{t}+\gamma_{2} H M L_{t}+\varepsilon_{t},
$$

where $S M B_{t}$ is the size factor constructed as a zero-investment portfolio that is long in small cap stocks and short in large cap stocks, and $H M L_{t}$ is a zero-investment portfolio that is long in high book-to-market stocks and short in low book-to-market stocks. ${ }^{5}$ We are again interested in the magnitude of $\alpha$ which captures the out- or underperformance of a specific fund.

The final extension to the asset pricing model is the inclusion of a fourth factor, the momentum factor. This factor is based on the empirical results of Jegadeesh and Titman (1993), who find that stocks that have performed relatively well in the past, tend to continue to perform well in the near future, and vice versa. This phenomenon, known as momentum effect, has been observed consistently over time. Furthermore,

\footnotetext{
${ }^{5}$ For more details of these factors and their construction, please refer to: http://mba.tuck.dartmouth.edu/pages/faculty/ken.french/data/library.html
} 
Carhart (1997) shows that the momentum factor can explain mutual fund returns beyond the 3-factor model proposed originally by Fama and French (1993). Carhart (1997) shows that, after controlling for the momentum factor, little evidence on the outperformance for equity mutual funds remains. Since it may be the case that the effect of efficiency on firm performance is driven by the momentum effect, we add this control variable and estimate the Carhart (1997) 4-factor model:

$$
R_{t}=\alpha+\beta R M R F_{t}+\gamma_{1} S M B_{t}+\gamma_{2} H M L_{t}+\gamma_{3} W M L_{t}+\varepsilon_{t},
$$

where $W M L_{t}$ is the return on a zero-investment momentum strategy going long in past winners (those firms that had the best stock price performance in the past year) and short in past losers. ${ }^{6}$

\subsection{Market Timing}

The last assessment we conduct on KiwiSaver Funds is whether there is any evidence on market timing skills of fund managers. Market timing skills would be present if fund managers could time the market and increase market exposure when there is an increase in stock prices and decrease market exposure in times when the market is going down. To assess market timing skills, we need to extend the one factor model to capture the possible non-linearity of fund portfolio and market returns. This is originally proposed by Treynor and Mazuy (1966). We follow their framework of by augmenting a CAPM regression with a squared term, i.e.,

\footnotetext{
${ }^{6}$ Again for details of this risk-factor, please see http://mba.tuck.dartmouth.edu/pages/faculty/ken.french/data\_library.html
} 


$$
R_{t}=\alpha+\beta R M R F_{t}+\delta R M R F_{t}^{2}+\varepsilon_{t}
$$

In this equation $\delta$ captures fund managers' market timing skills. A positive value for $\delta$ would indicate successful market timing skills, whereas a negative value for $\delta$ indicates that a manager would time the market "the wrong way around", i.e. increasing market exposure when market returns are low and vice versa.

\section{Data}

We obtain monthly return data on KiwiSaver funds from Morningstar over the period September 2007 to April 2013. The returns are net of fees. For the same period, we obtain the 90-day bank bill, as a proxy for the risk-free rate, from the Reserve Bank of New Zealand (www.rbnz.govt.nz). Finally, we obtain data on benchmarks from Kenneth French's

website

(http://mba.tuck.dartmouth.edu/pages/faculty/ken.french/datal_library.html). This website contains data on the global market portfolio, and the global factors on SMB, HML, and WML. We convert the returns on these portfolios to New Zealand Dollar.

\section{Empirical Findings}

In this section, we present the results for the analyses based on methodologies presented in Section 2. We start by assessing the replicability of KiwiSaver funds within a fund family. Second, we assess the performance of KiwiSaver Growth funds. 
Finally, we test whether there is any evidence of market timing skills by mutual fund managers.

\subsection{Replicability of KiwiSaver Funds}

To assess the replicability of KiwiSaver funds within a specific fund family, we select all KiwiSaver funds that have Moderate or Balanced funds (moderate risk) as well as conservative (low risk) and growth funds (high risk). For these KiwiSaver funds, we examine whether it is possible to create a synthetic fund (based on a combination of conservative and growth funds) that tracks a balanced or moderate fund. We report our results for this analysis in Table 1.

In the first columns of Table 1, we report the results for the constrained OLS regression in Equation (1), where we replicate funds based on the Conservative and Growth funds of a KiwiSaver fund provider; or, if available, we use the Conservative and Aggressive/Equity funds. The coefficients we report are essentially the weights that one would have to put onto the respective conservative or growth funds in order to replicate the fund. Within specific styles, we observe that there is quite some variation in weights. For instance, Grosvenor Balanced consists of a mix of $66 \%$ Conservative and $34 \%$ Growth, whereas Aon Balanced consists of a mix of $25 \%$ Conservative and $75 \%$ Growth.

In the next three columns, we report the fit of the reconstructed funds. If the reconstructed fund fits the actual fund, we expect $\alpha=0$ and $\beta=1$. Overall, we observe that this is the case for most of the funds. We further observe relatively high $\mathrm{R}^{2}$ values that are in all, except a few cases, greater than $95 \%$. The values for the F-tests indicate 
whether we can reject the null hypothesus that $\alpha=0$ and $\beta=1$. In most cases, we observe that we cannot reject this null hypothesis, but we find significant results for some of the funds (e.g. the SIL and ANZ funds do not seem to be simple replications of a Conservative and Growth fund; Staples Balanced is not a simple mix of the other funds either). This can be because these funds indeed have different asset mixes (see e.g. Staples Balanced, which produces an $\alpha$ that is very different from zero, a $\beta$ that is very different from 1 ; and a relatively low $R^{2}$ ) or could be due to some other factors (see e.g. SIL Balanced, which produces a very high $R^{2}$ and $\beta=1$, but has a significantly negative $\alpha$ ).

To provide a visual representation of the fit between actual and replicated funds, we show the performance of $\$ 1$ invested in the actual versus the replicated fund for the Aon Balanced fund (Panel A) and the AMP Moderate Balanced fund (Panel B). As can be seen from both graphs the fit between the actual fund and the replicated one are very close.

The last column of Table 1 reports the fees of the actual fund versus the fees of the replicated fund (which are based on a weighted average of Conservative and Growth) ${ }^{7}$. We note that for most of the funds that we can replicate successfully (i.e. those that produce an insignificant F-test) the difference between actual fees and the fees on the reconstructed funds are negative. We find particularly large negative values for the AMP funds suggesting that these funds can be replicated cheaper than what they are

\footnotetext{
${ }^{7}$ Note that fees should not be compared between the different KiwiSaver providers, as these funds do not represent the total fees charged in all cases. Fees are based on what fund providers report in their investment statements. Some providers only report total fees, some provide management fees, etc. However, the fees that we report do capture all fees that vary across the different investment styles of the funds.
} 
offered for to investors, whereas other funds, like Aon seem to price their funds relatively accurately.

\subsection{Performance Attribution Regressions}

In this section, we assess the performance of KiwiSaver funds, by comparing them with various benchmarks. Here, we only focus on the Growth or Aggressive/Equity funds.

\section{INSERT TABLE 2 HERE}

In Table 2, we report annual returns and standard deviation since the inception of these funds. We note that both returns and standard deviation show considerable variation among funds. Returns since inception are highest for Brook Growth at 5.91\% p.a. and lowest for the SmartShares Growth fund at $0.01 \%$ p.a. Interestingly, we note that the SmartShares fund has the highest risk profile based on the standard deviation, whereas Brook Growth has one of the lowest standard deviations among the Growth funds. Hence, the traditional relationship between risk and return, i.e., higher riskhigher return, since the inception of the KiwiSaver funds appears not to have held over this period. The observed negative relationship between risk and return could mainly be attributed to the recent Global Financial Crisis, where equities have performed poorly relatively to asset types, in particular fixed income assets. Based on the reported statistics, one can observe unusually large differences in risk, captured by the standard deviation. Among the growth funds, the fund with the highest risk, SmartShares Growth, is nearly twice as risky as Westpac Growth, being the least risky one. This particular finding suggests that there is a wide variation in the asset 
allocation of the different growth funds, some tilting more heavily to equity and some more to fixed income assets, or possibly more to low risk versus high risk stocks. Investors need to be cautioned that a comparison on the basis of returns, as usually reported in the new papers and financial press, alone will not be very meaningful.

The remaining columns in Table 2 report the results of the regression of excess fund returns on the excess returns of the NZX50 index and the ASX 200 index. Overall, we note that all of the funds in our sample exhibit significant exposures to the two market indices. The $R^{2}$ s of these regressions indicate how much of the variation of the funds can be explained by the returns on the NZX50 and the ASX 200. Here, we observe wide variation between these funds. For some of the funds more than $85 \%$ of their variation can be explained by the returns on these two market indices (ASB, Westpac, Onepath, ANZ, SIL and Tower), whereas other funds seems to make considerably different investments and yield relatively low $R^{2}$ s (Staples Rodway [58.33\%], Aon [60.31\%], and Brook [62.24], among others). Interestingly, when we consider the $\alpha$ 's of the regressions (measuring the relatively out- or under-performance), we note that six of the funds seem to be able to outperform (yield positive and significant $\alpha$ ) the two market indices. These are Brook, Westpac, Onepath, ANZ, SIL, and Tower. We find no evidence for significant underperformance, as far as investing in these two markets are concerned.

\section{INSERT TABLE 3 HERE}

We continue our analysis by comparing the performance of each fund with the performance of a global market index and report the results for this regression in 
Table 3. Our first coefficient of interest is the exposure that each fund has to the global market portfolio $(\beta)$ as this represents the total amount of market risk in a fund. We note a wide variation in the total market risk with Tower Equity having the largest exposure (0.891) and AMP Growth having the lowest exposure (0.431), less than half the exposure of Tower Equity has. All other funds are dispersed relatively evenly between these two extremes. This finding again demonstrates the large variation in risk taking attitude and exposure among KiwiSaver "growth" funds. We also note the

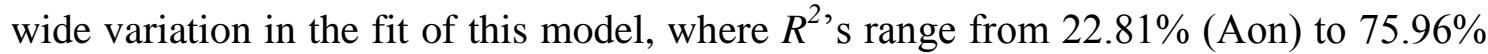
(Grosvenor), suggesting that some funds tend to have a global investment strategy, whereas others do not. A comparison between $R^{2 \text {, }}$ s of these regressions and the previous regression on the local market indices provides a strong indication of where the investment focuses of the different funds lie. Finally, when we consider the $\alpha$ of each fund, we find that in all but one case $\alpha$ 's are negative, and in one case we have weak significant evidence (Grosvenor). Our findings suggest that none of the KiwiSaver Growth funds systematically outperform the global benchmark.

In Table 4, we report the results for the Fama and French 3-factor model, which augments the CAPM by including two additional factors that captures the size and the value effects, respectively. Based on the results reported in Table 4, we first note that the inclusion of these factors causes a substantial increase in the $R^{2}$ s $\mathrm{s}$ of the regressions, suggesting that we make substantial improvements in terms of the fit of the model by including these factors. In most cases, the $R^{2}$ 's of these regressions

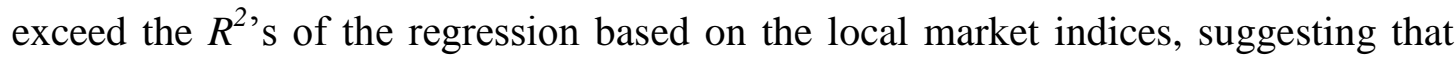
with the inclusion of these factors, we able to capture the same or more variation of fund returns than just with the two local market indices. 


\section{INSERT TABLE 4 HERE}

When we consider the factor loadings on SMB, we observe that in most cases these are negative, and in 13 out of 19 cases significantly so. This finding suggests that for the majority of funds the investment focus is more on large companies, rather than small companies. For the HML factor loading, we find predominantly negative loadings, which in 11 cases are statistically significant. This finding indicates that most of the funds have a significantly higher exposure to "glamour" stock (low bookto-market values) than to value stocks. When we consider the $\alpha$ 's for these funds again, we note that in all but one case they are negative and in eight cases they are significantly negative. On the whole, we report that after controlling for these two additional risk factors, a substantial proportion of KiwiSaver growth funds underperform relative to these benchmarks.

In Table 5, we report the results for the Carhart (1997) 4-factor model, which allows for an extra risk factor, the momentum. Overall, we note that the addition of the momentum factor does not increase the fit of the model substantially. Only in five cases do we observe a significant loading on the momentum factor, which is negative, suggesting that these funds do not employ momentum trading strategies, but rather show contrarian behaviour. In terms of outperformance, we observe that $\alpha$ 's of the funds remain largely negative, with some funds again having significantly negative $\alpha$ 's. 


\section{INSERT TABLE 5 HERE}

\subsection{Market Timing Skills}

In Table 6, we report the results for Equation (6), which considers the market timing skills of KiwiSaver fund managers. In this table, we are interested in the coefficient on the square of the excess market return. If this coefficient is positive and significant, it provides evidence of positive market timing skills, i.e. fund managers increase the exposure to equity when returns go up, whereas a negative coefficient suggests negative market timing skills, i.e. fund managers increase their exposure to equity when equity performs poorly.

\section{INSERT TABLE 6 HERE}

From the results reported in Table 6, we clearly observe that there is no evidence of significantly positive market timing skills. For the majority of funds in our sample, we find that the exposure to the square of excess market returns is negative, and in six of the cases we observe evidence of significantly negative market timing skills. These significantly negative market timing skills are observed for AMP Aggressive, AMP Growth, OnePath and ANZ Growth, and, to a lesser extent, for Staples Rodway and Tower Growth. ${ }^{8}$

\footnotetext{
${ }^{8}$ We have also carried out analysis regarding the market timing abilities of fund managers using the NZX market index, in no single case there was any evidence of superior market timing. Furthermore, we have conducted an analysis of style timing, by including squares of the SMB and HML factor, but find no evidence of funds engaging in style timing.
} 


\section{Conclusions}

The KiwSaver funds and their performance have not yet been widely examined so far. The present study investigates some of the pertinent issues, namely, the replicability of KiwiSaver funds (based on their Conservative and Growth strategies) and the risk adjusted performance of the KiwiSaver growth funds, i.e. those with the largest exposure to equity investments. We also assess market timing skills of the fund managers. We find that for the majority of fund providers, moderate and balanced funds are linear combinations of the conservative and growth. Interestingly, we note that within the family of funds of the same provider, the replicated funds will incur lower fees than the actual funds, suggesting some mispricing in the calculation of fees.

When we further examine the performance of KiwiSaver "Growth" funds, we find that there is substantial difference in the amount of risk-taking and stock market exposure, making it very difficult to compare these funds simply based on returns. Risk-adjusted performance based on commonly used performance measurement techniques reveals that there is no evidence of systematic outperformance of these funds, and in several cases we find evidence of systematic underperformance. We also find that none of the KiwiSaver funds in our sample exploit the well-known "size effect" by exposing their fund to small-cap or the "value effect", by exposing their fund to value stocks. Also, none of the funds follow the well-known momentum strategy to generate outperformance. Finally, when we assess the market timing skills of KiwiSaver fund managers, we observe no evidence for significant positive market timing skills, and in several cases we find significant negative market timing skills. 
Overall, our results suggest that KiwiSaver investors need to be prudent in terms of the selection of KiwiSaver fund provider, as these funds differ substantially in their degree of risk taking. Our results also suggest that there are potential shortcomings in the investment opportunities to KiwiSaver investors, as the KiwiSaver funds, at least those examined in our sample, do not offer investors with the opportunities to invest in small cap and value stocks. 


\section{References}

Andersen, T., Bollerslev, T., Diebold, F. and Labys, P. (2003). Modeling and Forecasting Realized Volatility. Econometrica 71, 579-625.

Banz, R., (1981). The Relationship between Return and Market Value of Common Stocks. Journal of Financial Economics 9, 3-18.

Bauer, R., R. Otten, and Tourani-Rad, A., (2006). New Zealand Mutual Funds: Measuring Performance and Persistence in Performance, Accounting and Finance 43, 347-363.

Black, F., (1972). Capital Market Equilibrium with Restricted Borrowing. Journal of Business 45, 444-455.

Carhart, M., (1997). On the Persistence in Mutual Fund Performance. Journal of Finance 52, 57-82.

Chen, J., H. Hong, M., Huang, and Kubik J., (2004)) Does Fund Size Erode Mutual Fund Performance? The Role of Liquidity and Organization. American Economic Review 94, 1276-1302.

Del Guerico, D. and Tkac, P., (2002). The Determinants of the Flow of Funds of Managed Portfolios: Mutual Funds vs. Pension Funds. Journal of Financial and Quantitative Analysis, 37, 523-557.

Fama, E., and French, K., (1992). The Cross-section of Expected Stock Returns. Journal of Finance 47, 427-465.

Fama, E., and French, K., (1993). Common Risk Factors in the Returns on Stocks and Bonds. Journal of Financial Economics 33, 3-56.

Fama, E., and French, K., (2008). Mutual Fund Performance. Working paper. 
Gil-Bazo, J.,and Ruiz-Verdu P., (2009). The Relation Between Price and Performance in the Mutual Fund Industry, Journal of Finance 64, 2153-2183.

Hendricks, D., J., Patel, and Zekhauser, R (1993). Hot Hands in Mutual Funds: ShortRun Persistence of Relative Performance, 1974-1988, Journal of Finance 48, 93-130.

Kritzer, B., (2007) KiwiSaver: New Zealand's New Subsidized Retirement Saving Plan, Social Security Bulletin 67, 113-119.

Jegadeesh, N. and Titman, S., (1993). Returns to Buying Winners and Selling Losers: Implications for Stock Market Efficiency Journal of Finance 48, 65-91.

MacDonald, K., Bianchi, R. and Drew, M. (2012). KiwiSaver and Retirement Adequacy, Australian Accounting Business and Finance Journal 6, 61-78.

Malkiel, G., (1995) Returns from Investing in Equity Mutual Funds 1971 to 1991. Journal of Finance 50, 549-72.

Scobie, G. and Henderson, K., (2009) Household Debt in New Zealand, Working Paper series, The Treasury, http://www.treasury.govt.nz/publications/researchpolicy/wp/2009/09-03

Sharpe, W., (1964). Capital Asset Prices: A Theory of Market Equilibrium under Conditions of Risk. Journal of Finance 19, 425-442.

Swinkels, L., and Tjong-a-Tjoe, L., 2007. Can Mutual Funds Time Investment Styles? Journal of Asset Management 8, 123-132.

Thomas, C., and Matthews, C., (2013) KiwiSaver Member Behaviour: A Quantitative Analysis, unpublished manuscript, Massey Unversity.

Treynor, J. and Mazuy, K., (1966). Can Mutual Funds Outguess the Market? Harvard Business Review 44, 131-136. 
Zheng, L., (1999). “Is Money Smart? A Study of Mutual Fund Investors' Fund Selection Ability." Journal of Finance 54, 901-33.

Zhang, A. (2013). Financial Advice and Asset Allocation Choices of Individual Investors: Evidence from New Zealand, unpublished manuscript, Auckland University of Technology. 
Table 1. Replication of Funds

\begin{tabular}{|c|c|c|c|c|c|c|c|c|c|c|}
\hline \multirow[b]{2}{*}{ Fund } & \multicolumn{3}{|c|}{ Constrained OLS } & \multicolumn{4}{|c|}{ Fit of Reconstructed Funds } & \multicolumn{3}{|c|}{ Fees } \\
\hline & Conservative & Growth & $\begin{array}{l}\text { Aggressivel } \\
\text { Equity }\end{array}$ & $\alpha$ & (5) & $R^{2}$ & $F$-test & $\begin{array}{l}\text { Fund } \\
\text { Fees }\end{array}$ & $\begin{array}{l}\text { Reconstructed } \\
\text { Fees }\end{array}$ & Diff. \\
\hline AMP Moderate & $0.73(143.88)$ & $0.27(52.47)$ & & $0.012(0.93)$ & $1.01(98.57)$ & $99.34 \%$ & 0.99 & $0.975 \%$ & $0.9177 \%$ & $-0.05734 \%$ \\
\hline AMP Moderate & $0.796(158.23)$ & & $0.21(43.15)$ & $0.018(1.08)$ & $1.01(81.50)$ & $99.03 \%$ & 1.01 & $0.975 \%$ & $0.9328 \%$ & $-0.04225 \%$ \\
\hline AMP Moderate Balanced & $0.49(377.46)$ & $0.51(391.61)$ & & $0.005(1.61)$ & $1.00(564.20)$ & $99.98 \%$ & 1.57 & $1.025 \%$ & $0.9556 \%$ & $-0.06942 \%$ \\
\hline AMP Moderate Balanced & $0.59(223.62)$ & & $0.41(155.49)$ & $0.0137(1.61)$ & $1.00(225.37)$ & $99.87 \%$ & 1.76 & $1.025 \%$ & $0.9775 \%$ & $-0.0475 \%$ \\
\hline AMP Balanced & $0.36(66.49)$ & $0.64(118.06)$ & & $-0.021(-1.51)$ & $0.99(161.02)$ & $99.75 \%$ & $2.68 *$ & $1.025 \%$ & $0.9761 \%$ & $-0.04888 \%$ \\
\hline AMP Balanced & $0.48(119.40)$ & & $0.52(127.32)$ & $-0.011(-0.85)$ & $0.99(169.95)$ & $99.78 \%$ & 0.98 & $1.025 \%$ & $1.0050 \%$ & $-0.02 \%$ \\
\hline AMP Growth & $0.19(55.10)$ & & $0.81(228.76)$ & $0.017(1.51)$ & $1.00(277.37)$ & $99.92 \%$ & 1.32 & $1.033 \%$ & $1.0775 \%$ & $0.0445 \%$ \\
\hline Aon Moderate & $0.64(55.02)$ & $0.36(31.12)$ & & $0.038(1.20)$ & $0.98(74.25)$ & $98.82 \%$ & 1.64 & $0.94 \%$ & $0.9384 \%$ & $-0.0016 \%$ \\
\hline Aon Balanced & $0.25(47.39)$ & $0.75(140.16)$ & & $0.214(1.50)$ & $1.00(230.75)$ & $99.88 \%$ & 1.30 & $1.01 \%$ & $1.0125 \%$ & $0.0025 \%$ \\
\hline ASB Moderate & $0.64(63.22)$ & $0.36(35.81)$ & & $-0.028(-1.08)$ & $0.97(61.98)$ & $98.34 \%$ & $2.99 *$ & $0.60 \%$ & $0.5080 \%$ & $-0.092 \%$ \\
\hline ASB Balanced & $0.32(49.19)$ & $0.69(107.16)$ & & $-0.022(-1.34)$ & 0.99 (146.57) & $99.70 \%$ & 1.66 & $0.65 \%$ & $0.6110 \%$ & $-0.039 \%$ \\
\hline ANZ Cons. Balanced & $0.75(307.60)$ & $0.25(103.25)$ & & $-0.011 *(-1.75)$ & $1.00(210.73)$ & $99.85 \%$ & $3.08 *$ & $1.02 \%$ & $1.0575 \%$ & $0.0375 \%$ \\
\hline ANZ Balanced & $0.51(227.02)$ & $0.50(222.27)$ & & $-0.014 * * *(-2.70)$ & $1.00(347.40)$ & $99.95 \%$ & $4.88^{* *}$ & $1.07 \%$ & $1.1052 \%$ & $0.0352 \%$ \\
\hline ANZ Balanced Growth & $0.25(147.43)$ & $0.75(436.52)$ & & $-0.009^{* *}(-2.19)$ & $1.00(591.58)$ & $99.98 \%$ & $3.23 * *$ & $1.12 \%$ & $1.1325 \%$ & $0.0125 \%$ \\
\hline BT Westpac Balanced & $0.29(13.09)$ & $0.71(32.20)$ & & $-0.0167(-0.49)$ & $0.97(54.72)$ & $97.84 \%$ & 2.14 & $0.65 \%$ & $0.6565 \%$ & $0.0065 \%$ \\
\hline Fidelity Balanced & $0.50(28.81)$ & $0.50(29.20)$ & & $-0.0228(-0.75)$ & $0.99(61.48)$ & $98.31 \%$ & 0.72 & $1.19 \%$ & $1.1550 \%$ & $-0.035 \%$ \\
\hline Grosvenor Balanced & $0.66(97.63)$ & $0.34(51.25)$ & & $-0.017(-0.99)$ & $1.01(115.64)$ & $99.52 \%$ & 0.76 & $1.07 \%$ & $1.0380 \%$ & $-0.032 \%$ \\
\hline Mercer Balanced & $0.41(70.70)$ & $0.59(103.64)$ & & $-0.00(-0.06)$ & $0.99(167.04)$ & $99.77 \%$ & 2.10 & $0.72 \%$ & $0.6888 \%$ & $-0.0312 \%$ \\
\hline OnePath Cons Balanced & $0.76(175.99)$ & $0.25(57.05)$ & & $-0.008(-0.78)$ & $0.99(117.17)$ & $99.52 \%$ & 1.03 & $0.60 \%$ & $0.6106 \%$ & $0.0106 \%$ \\
\hline OnePath Balanced & $0.51(12.62)$ & $0.49(12.23)$ & & $-0.016(-0.19)$ & $0.84(17.95)$ & $83.00 \%$ & $6.51 * * *$ & $0.65 \%$ & $0.6482 \%$ & $-0.0018 \%$ \\
\hline OnePath Balanced Growth & $0.25(132.66)$ & $0.75(393.00)$ & & $0.001(0.14)$ & $1.00(510.10)$ & $99.98 \%$ & 0.14 & $0.70 \%$ & $0.6950 \%$ & $-0.005 \%$ \\
\hline SIL Cons Balanced & $0.75(297.63)$ & $0.26(101.83)$ & & $-0.013 * *(-2.06)$ & $1.00(206.98)$ & $99.85 \%$ & $3.65^{* *}$ & $1.06 \%$ & $1.1096 \%$ & $0.0496 \%$ \\
\hline SIL Balanced & $0.51(247.65)$ & $0.49(241.17)$ & & $-0.016^{* * * *}(-3.34)$ & $1.00(386.35)$ & $99.96 \%$ & $7.01 * * *$ & $1.11 \%$ & $1.1335 \%$ & $0.0235 \%$ \\
\hline SIL Balanced Growth & $0.25(134.39)$ & $0.75(400.93)$ & & $-0.013 * * *(-2.99)$ & $1.00(557.98)$ & $99.98 \%$ & $5.47 * * *$ & $1.16 \%$ & $1.1725 \%$ & $0.0125 \%$ \\
\hline Staples Balanced & $0.14(2.15)$ & $0.86(12.78)$ & & 0.1647 (1.07) & $0.71(12.26)$ & $69.81 \%$ & $13.20 * * *$ & $1.05 \%$ & $1.1440 \%$ & $0.094 \%$ \\
\hline Tower Balanced & $0.56(25.14)$ & $0.44(19.40)$ & & $-0.014(-0.30)$ & $0.96(42.79)$ & $96.52 \%$ & 1.43 & $0.98 \%$ & $0.9724 \%$ & $-0.0076 \%$ \\
\hline Tower Balanced & $0.74(57.03)$ & & $0.26(19.70)$ & $-0.031(-0.68)$ & $0.96(43.75)$ & $96.67 \%$ & $2.76^{*}$ & $0.98 \%$ & $0.9450 \%$ & $-0.035 \%$ \\
\hline Tower Growth & $0.43(23.04)$ & & $0.57(30.26)$ & $-0.024(-0.38)$ & $0.95(46.68)$ & $97.06 \%$ & $2.98 *$ & $1.09 \%$ & $0.9997 \%$ & $-0.0903 \%$ \\
\hline
\end{tabular}

funds show the regression results for Equation (2), where we expect $\alpha=0$ and $\beta=1$. The F-test is a test for the joint significance of $\alpha$ and $\beta$. Fund fees either represent total fees or total variable fees as they are reported by the funds in their investment statements (given that the reporting of fees is not consistent across funds, fees should not be compared between funds). Reconstructed 
fees are the fees based on the reconstructed funds, and Diff. shows the difference between the fees on the reconstructed fund and the fund fees. T-statistics are reported in parentheses and $*$ $* *$, and $* * *$ indicate significance at the $10 \%, 5 \%$, and $1 \%$ levels, respectively. 
Table 2. Performance Relative to the NZ and Australian Stock Markets

\begin{tabular}{|c|c|c|c|c|c|c|c|}
\hline & Obs & $\begin{array}{l}\text { Return } \\
\text { (\% p.a.) }\end{array}$ & $\begin{array}{l}\text { St. Dev. } \\
(\% \text { p.a. })\end{array}$ & $\alpha$ & $N Z X 50$ & $A S X 200$ & $R^{2}$ \\
\hline AMP Aggressive & 67 & $1.27 \%$ & $13.08 \%$ & $\begin{array}{l}0.041 \\
(0.19)\end{array}$ & $\begin{array}{r}0.400 * * * \\
(3.22)\end{array}$ & $\begin{array}{r}0.308 * * * \\
(2.95)\end{array}$ & $59.32 \%$ \\
\hline AMP Growth & 67 & $1.90 \%$ & $10.91 \%$ & $\begin{array}{r}0.057 \\
(0.32)\end{array}$ & $\begin{array}{r}0.348 * * * \\
(3.22)\end{array}$ & $\begin{array}{r}0.251^{* * *} * \\
(2.90)\end{array}$ & $60.02 \%$ \\
\hline AON Growth & 67 & $3.96 \%$ & $13.78 \%$ & $\begin{array}{l}0.301 \\
(1.23)\end{array}$ & $\begin{array}{r}0.462 * * * \\
(3.85)\end{array}$ & $\begin{array}{r}0.300 * * * \\
(2.76)\end{array}$ & $60.31 \%$ \\
\hline ASB Growth & 67 & $2.51 \%$ & $10.94 \%$ & $\begin{array}{l}0.139 \\
(1.22)\end{array}$ & $\begin{array}{r}0.385 * * * \\
(7.93)\end{array}$ & $\begin{array}{r}0.333 * * * \\
(11.17)\end{array}$ & $87.97 \%$ \\
\hline Brook Growth & 67 & $5.91 \%$ & $8.72 \%$ & $\begin{array}{r}0.359 * \\
(1.86)\end{array}$ & $\begin{array}{r}0.308 * * * \\
(4.05)\end{array}$ & $\begin{array}{r}0.182 * * * \\
(3.85)\end{array}$ & $62.24 \%$ \\
\hline Westpac Growth & 67 & $3.94 \%$ & $8.06 \%$ & $\begin{array}{r}0.245 * * * \\
(3.12)\end{array}$ & $\begin{array}{r}0.399 * * * \\
(10.24)\end{array}$ & $\begin{array}{r}0.166^{* * * *} \\
(6.43)\end{array}$ & $89.58 \%$ \\
\hline Fidelity Growth & 67 & $4.12 \%$ & $9.12 \%$ & $\begin{array}{r}0.226 \\
(1.60)\end{array}$ & $\begin{array}{r}0.333 * * * \\
(3.74)\end{array}$ & $\begin{array}{r}0.209 * * * \\
(4.36)\end{array}$ & $69.50 \%$ \\
\hline Fidelity Agg & 67 & $3.80 \%$ & $11.61 \%$ & $\begin{array}{l}0.235 \\
(1.21)\end{array}$ & $\begin{array}{r}0.368 * * * \\
(6.67)\end{array}$ & $\begin{array}{r}0.317^{* * * *} \\
(8.90)\end{array}$ & $72.23 \%$ \\
\hline Fisher Growth & 67 & $5.34 \%$ & $12.80 \%$ & $\begin{array}{l}0.372 \\
(1.56)\end{array}$ & $\begin{array}{r}0.366 * * * \\
(4.68)\end{array}$ & $\begin{array}{r}0.396 * * * \\
(5.06)\end{array}$ & $75.79 \%$ \\
\hline Forsyth Barr Growth & 58 & $2.36 \%$ & $8.76 \%$ & $\begin{array}{l}-0.114 \\
(-1.04)\end{array}$ & $\begin{array}{r}0.329 * * * \\
(6.88)\end{array}$ & $\begin{array}{r}0.275^{* * * *} \\
(4.79)\end{array}$ & $84.23 \%$ \\
\hline Grosvenor High Growth & 67 & $0.62 \%$ & $11.94 \%$ & $\begin{array}{r}0.000 \\
(0.00)\end{array}$ & $\begin{array}{r}0.414 * * * \\
(5.58)\end{array}$ & $\begin{array}{r}0.343 * * * \\
(7.60)\end{array}$ & $82.60 \%$ \\
\hline Mercer High Growth & 67 & $1.60 \%$ & $12.55 \%$ & $\begin{array}{r}0.106 \\
(0.65)\end{array}$ & $\begin{array}{r}0.454 * * * \\
(10.54)\end{array}$ & $\begin{array}{r}0.354 * * * \\
(6.56)\end{array}$ & $83.30 \%$ \\
\hline OnePath growth & 67 & $3.03 \%$ & $9.64 \%$ & $\begin{array}{r}0.208 * * \\
(2.36)\end{array}$ & $\begin{array}{r}0.453 * * * \\
(13.61)\end{array}$ & $\begin{array}{r}0.222 * * * \\
(9.28)\end{array}$ & $91.27 \%$ \\
\hline ANZ Growth & 67 & $4.21 \%$ & $10.38 \%$ & $\begin{array}{r}0.312 * * * \\
(3.18)\end{array}$ & $\begin{array}{r}0.458 * * * \\
(9.94)\end{array}$ & $\begin{array}{r}0.255^{* * * *} \\
(8.24)\end{array}$ & $89.45 \%$ \\
\hline SIL Growth & 67 & $4.38 \%$ & $10.37 \%$ & $\begin{array}{r}0.327 * * * \\
(3.35)\end{array}$ & $\begin{array}{r}0.459 * * * \\
(9.96)\end{array}$ & $\begin{array}{r}0.253 * * * \\
(7.91)\end{array}$ & $89.35 \%$ \\
\hline Smart Growth & 67 & $0.01 \%$ & $15.58 \%$ & $\begin{array}{l}0.122 \\
(0.69)\end{array}$ & $\begin{array}{r}0.725^{* * *} * \\
(10.40)\end{array}$ & $\begin{array}{r}0.279 * * * \\
(4.42)\end{array}$ & $77.47 \%$ \\
\hline Staples Rodway Growth & 66 & $4.29 \%$ & $9.20 \%$ & $\begin{array}{l}0.212 \\
(1.45)\end{array}$ & $\begin{array}{r}0.247 * * * \\
(2.71)\end{array}$ & $\begin{array}{r}0.236 * * * \\
(2.94)\end{array}$ & $58.33 \%$ \\
\hline TOWER Growth & 67 & $2.93 \%$ & $10.88 \%$ & $\begin{array}{r}0.211^{*} \\
(1.84)\end{array}$ & $\begin{array}{r}0.463 * * * \\
(9.46)\end{array}$ & $\begin{array}{r}0.263 * * * \\
(6.09)\end{array}$ & $85.24 \%$ \\
\hline TOWER Equity & 67 & $0.44 \%$ & $15.68 \%$ & $\begin{array}{l}0.032 \\
(0.16)\end{array}$ & $\begin{array}{r}0.462 * * * \\
(5.84)\end{array}$ & $\begin{array}{r}0.509 * * * \\
(8.16)\end{array}$ & $81.13 \%$ \\
\hline
\end{tabular}

This table reports average return and risk (standard deviation) over the sample period. We also report the regression results for a model that includes the NZX50 and the ASX200 as benchmarks. Obs. is the number of observations Return and St. Dev. are the annual average return and standard deviation, respectively, $\alpha$ measures the risk-adjusted performance relative to the benchmarks, NZX50 and ASX200 show the coefficients on the on the excess return on the NZX50 and ASX200, and $R^{2}$ measures the goodness of fit. Newey-West corrected t-statistics are reported in parentheses and *, **, and *** indicate significance at the $10 \%, 5 \%$, and $1 \%$ levels, respectively. 
Table 3. Performance measurement using the CAPM

\begin{tabular}{|c|c|c|c|c|}
\hline & Obs. & $\alpha$ & RMRF & $\overline{R^{2}}$ \\
\hline AMP Aggressive & 67 & $\begin{array}{r}-0.309 \\
(-0.77)\end{array}$ & $\begin{array}{r}0.504 * * * \\
(3.95)\end{array}$ & $25.60 \%$ \\
\hline AMP Growth & 67 & $\begin{array}{l}-0.243 \\
(-0.72)\end{array}$ & $\begin{array}{r}0.431 * * * \\
(4.10)\end{array}$ & $26.69 \%$ \\
\hline AON Growth & 67 & $\begin{array}{l}-0.083 \\
(-0.17)\end{array}$ & $\begin{array}{r}0.502 * * * \\
(4.38)\end{array}$ & $22.81 \%$ \\
\hline ASB Growth & 67 & $\begin{array}{l}-0.232 \\
(-0.85)\end{array}$ & $\begin{array}{r}0.680 * * * \\
(9.91)\end{array}$ & $65.72 \%$ \\
\hline Brook Growth & 67 & $\begin{array}{c}0.078 \\
(0.35)\end{array}$ & $\begin{array}{r}0.512 * * * \\
(5.82)\end{array}$ & $60.15 \%$ \\
\hline Westpac Growth & 67 & $\begin{array}{c}-0.088 \\
(-0.45)\end{array}$ & $\begin{array}{r}0.521 * * * \\
(12.21)\end{array}$ & $70.07 \%$ \\
\hline Fidelity Growth & 67 & $\begin{array}{l}-0.085 \\
(-0.53)\end{array}$ & $\begin{array}{r}0.594 * * * \\
(8.45)\end{array}$ & $73.32 \%$ \\
\hline Fidelity Aggressive & 67 & $\begin{array}{l}-0.132 \\
(-0.51)\end{array}$ & $\begin{array}{r}0.734 * * * \\
(11.48)\end{array}$ & $69.14 \%$ \\
\hline Fisher Growth & 67 & $\begin{array}{l}-0.002 \\
(-0.01)\end{array}$ & $\begin{array}{r}0.728 * * * \\
(6.35)\end{array}$ & $55.52 \%$ \\
\hline Forsyth Barr Growth & 58 & $\begin{array}{r}-0.270 \\
(-0.84)\end{array}$ & $\begin{array}{r}0.457 * * * \\
(4.92)\end{array}$ & $43.48 \%$ \\
\hline Grosvenor High Growth & 67 & $\begin{array}{r}-0.406^{*} \\
(-1.82)\end{array}$ & $\begin{array}{r}0.792 * * * \\
\quad(11.32)\end{array}$ & $75.96 \%$ \\
\hline Mercer High Growth & 67 & $\begin{array}{l}-0.298 \\
(-0.72)\end{array}$ & $\begin{array}{r}0.623 * * * \\
(5.90)\end{array}$ & $42.00 \%$ \\
\hline OnePath Growth & 67 & $\begin{array}{l}-0.171 \\
(-0.63)\end{array}$ & $\begin{array}{r}0.566 * * * \\
(7.61)\end{array}$ & $58.01 \%$ \\
\hline ANZ Growth & 67 & $\begin{array}{l}-0.082 \\
(-0.29)\end{array}$ & $\begin{array}{r}0.623 * * * \\
(9.40)\end{array}$ & $60.92 \%$ \\
\hline SIL Growth & 67 & $\begin{array}{l}-0.067 \\
(-0.24)\end{array}$ & $\begin{array}{r}0.621 * * * \\
(9.39)\end{array}$ & $60.70 \%$ \\
\hline Smart Growth & 67 & $\begin{array}{l}-0.446 \\
(-0.94)\end{array}$ & $\begin{array}{r}0.717 * * * \\
(5.67)\end{array}$ & $36.51 \%$ \\
\hline Staples Rodway Growth & 66 & $\begin{array}{l}-0.034 \\
(-0.13)\end{array}$ & $\begin{array}{r}0.449 * * * \\
(5.68)\end{array}$ & $41.29 \%$ \\
\hline TOWER Growth & 67 & $\begin{array}{r}-0.186 \\
(-0.61)\end{array}$ & $\begin{array}{r}0.613 * * * \\
(7.76)\end{array}$ & $54.00 \%$ \\
\hline TOWER Equity & 67 & $\begin{array}{l}-0.437 \\
(-1.18)\end{array}$ & $\begin{array}{r}0.891 * * * \\
(7.86)\end{array}$ & $55.91 \%$ \\
\hline
\end{tabular}

This table reports regression results for Equation (4). The benchmark $(R M R F)$ is the global market portfolio obtained from Kenneth French's website. Obs. is the number of observations, $\alpha$ measures the risk-adjusted performance relative to the benchmark, $R M R F$ is the excess return on the global market portfolio and $R^{2}$ measures the goodness of fit. Newey-West corrected t-statistics are reported in parentheses and $*, * *$, and $* * *$ indicate significance at the $10 \%, 5 \%$, and $1 \%$ levels, respectively. 
Table 4. Performance measurement using the Fama and French (1993) 3-Factor Model

\begin{tabular}{|c|c|c|c|c|c|c|}
\hline & Obs. & $\alpha$ & RMRF & SMB & $H M L$ & $R^{2}$ \\
\hline AMP Aggressive & 67 & $\begin{array}{r}-0.381 * \\
(-1.81)\end{array}$ & $\begin{array}{r}0.634 * * * \\
(8.25)\end{array}$ & $\begin{array}{l}-0.118 \\
(-1.47)\end{array}$ & $\begin{array}{r}-0.408 * * * \\
(-3.80)\end{array}$ & $67.23 \%$ \\
\hline AMP Growth & 67 & $\begin{array}{r}-0.302 * \\
(-1.67)\end{array}$ & $\begin{array}{r}0.537 * * * \\
(8.37)\end{array}$ & $\begin{array}{l}-0.099 \\
(-1.43)\end{array}$ & $\begin{array}{r}-0.333 * * * \\
(-3.65)\end{array}$ & $66.82 \%$ \\
\hline AON Growth & 67 & $\begin{array}{l}-0.154 \\
(-0.67)\end{array}$ & $\begin{array}{r}0.633 * * * \\
(8.40)\end{array}$ & $\begin{array}{r}-0.212 * * * \\
(-2.66)\end{array}$ & $\begin{array}{r}-0.366 * * * \\
(-2.92)\end{array}$ & $67.71 \%$ \\
\hline ASB Growth & 67 & $\begin{array}{r}-0.258 * * \\
(-2.07)\end{array}$ & $\begin{array}{r}0.737 * * * \\
(21.29)\end{array}$ & $\begin{array}{r}-0.258 * * * \\
(-5.25)\end{array}$ & $\begin{array}{l}-0.078 \\
(-1.50)\end{array}$ & $90.26 \%$ \\
\hline Brook Growth & 67 & $\begin{array}{l}0.081 \\
(0.40)\end{array}$ & $\begin{array}{r}0.515 * * * \\
(5.37)\end{array}$ & $\begin{array}{l}-0.180 \\
(-1.47)\end{array}$ & $\begin{array}{l}0.077 \\
(0.64)\end{array}$ & $65.66 \%$ \\
\hline Westpac Growth & 67 & $\begin{array}{l}-0.107 \\
(-0.80)\end{array}$ & $\begin{array}{r}0.560 * * * \\
(19.96)\end{array}$ & $\begin{array}{r}-0.122 * * * \\
(-3.12)\end{array}$ & $\begin{array}{r}-0.076^{*} \\
(-1.73)\end{array}$ & $85.14 \%$ \\
\hline Fidelity Growth & 67 & $\begin{array}{l}-0.089 \\
(-0.81)\end{array}$ & $\begin{array}{r}0.611 * * * \\
(7.96)\end{array}$ & $\begin{array}{r}-0.206 * * * \\
(-3.37)\end{array}$ & $\begin{array}{l}0.041 \\
(0.65)\end{array}$ & $83.31 \%$ \\
\hline Fidelity Aggressive & 67 & $\begin{array}{l}-0.155 \\
(-0.93)\end{array}$ & $\begin{array}{r}0.783 * * * \\
(16.62)\end{array}$ & $\begin{array}{r}-0.169 * * * \\
(-2.86)\end{array}$ & $\begin{array}{l}-0.090 \\
(-1.61)\end{array}$ & $82.01 \%$ \\
\hline Fisher Growth & 67 & $\begin{array}{l}-0.061 \\
(-0.21)\end{array}$ & $\begin{array}{r}0.827 * * * \\
(9.25)\end{array}$ & $\begin{array}{l}0.045 \\
(0.54)\end{array}$ & $\begin{array}{r}-0.377 * * * \\
(-3.39)\end{array}$ & $74.21 \%$ \\
\hline Forsyth Barr Growth & 58 & $\begin{array}{r}-0.326^{*} \\
(-1.75)\end{array}$ & $\begin{array}{r}0.551 * * * \\
(7.35)\end{array}$ & $\begin{array}{r}-0.048 \\
(-0.62)\end{array}$ & $\begin{array}{r}-0.239 * \\
(-1.89)\end{array}$ & $74.17 \%$ \\
\hline Grosvenor High Growth & 67 & $\begin{array}{r}-0.423 * * * \\
(-3.74)\end{array}$ & $\begin{array}{r}0.834 * * * \\
(19.72)\end{array}$ & $\begin{array}{r}-0.252 * * * \\
(-2.67)\end{array}$ & $\begin{array}{l}-0.027 \\
(-0.39)\end{array}$ & $90.78 \%$ \\
\hline Mercer High Growth & 67 & $\begin{array}{r}-0.349^{*} \\
(-1.87)\end{array}$ & $\begin{array}{r}0.724 * * * \\
(12.84)\end{array}$ & $\begin{array}{r}-0.285^{* * * *} \\
(-5.06)\end{array}$ & $\begin{array}{r}-0.222 * * \\
(-2.63)\end{array}$ & $83.42 \%$ \\
\hline OnePath Growth & 67 & $\begin{array}{l}-0.196 \\
(-1.30)\end{array}$ & $\begin{array}{r}0.621 * * * \\
\quad(14.65)\end{array}$ & $\begin{array}{r}-0.226 * * * \\
(-4.70)\end{array}$ & $\begin{array}{l}-0.084 \\
(-1.44)\end{array}$ & $84.25 \%$ \\
\hline ANZ Growth & 67 & $\begin{array}{l}-0.111 \\
(-0.68)\end{array}$ & $\begin{array}{r}0.683 * * * \\
(18.52)\end{array}$ & $\begin{array}{r}-0.222 * * * \\
(-4.98)\end{array}$ & $\begin{array}{r}-0.104 * * \\
(-1.98)\end{array}$ & $86.09 \%$ \\
\hline SIL Growth & 67 & $\begin{array}{l}-0.095 \\
(-0.59)\end{array}$ & $\begin{array}{r}0.681 * * * \\
(18.61)\end{array}$ & $\begin{array}{r}-0.226 * * * \\
(-5.00)\end{array}$ & $\begin{array}{r}-0.101 * \\
(-1.91)\end{array}$ & $86.01 \%$ \\
\hline Smart Growth & 67 & $\begin{array}{r}-0.488^{*} \\
(-1.76)\end{array}$ & $\begin{array}{r}0.811 * * * \\
(14.09)\end{array}$ & $\begin{array}{r}-0.463 * * * \\
(-4.51)\end{array}$ & $\begin{array}{r}-0.109 \\
(-1.00)\end{array}$ & $72.26 \%$ \\
\hline Staples Rodway Growth & 66 & $\begin{array}{l}-0.054 \\
(-0.31)\end{array}$ & $\begin{array}{r}0.511 * * * \\
(5.59)\end{array}$ & $\begin{array}{l}-0.085 \\
(-0.77)\end{array}$ & $\begin{array}{l}-0.176 \\
(-1.13)\end{array}$ & $61.79 \%$ \\
\hline TOWER Growth & 67 & $\begin{array}{l}-0.233 \\
(-1.49)\end{array}$ & $\begin{array}{r}0.701 * * * \\
\quad(15.11)\end{array}$ & $\begin{array}{r}-0.132 * * \\
(-2.39)\end{array}$ & $\begin{array}{r}-0.248 * * * \\
(-3.55)\end{array}$ & $84.77 \%$ \\
\hline TOWER Equity & 67 & $\begin{array}{r}-0.509 * * * \\
(-2.86)\end{array}$ & $\begin{array}{r}1.024 * * * \\
(21.19)\end{array}$ & $\begin{array}{r}-0.156^{* *} \\
(-2.03)\end{array}$ & $\begin{array}{r}-0.398 * * * \\
(-4.62)\end{array}$ & $88.07 \%$ \\
\hline
\end{tabular}

This table reports regression results for Equation (5), where the CAPM is augmented with the global $S M B$ and $H M L$ factors from Kenneth French's website. $O b s$. is the number of observations, $\alpha$ measures the risk-adjusted performance relative to the benchmark, $R M R F$ is the excess return on the global market portfolio, $S M B$ is the global size factor, $H M L$ is the global value factor, and $R^{2}$ measures the goodness of fit. Newey-West corrected t-statistics are reported in parentheses and *,**, and *** indicate significance at the $10 \%, 5 \%$, and $1 \%$ levels, respectively. 
Table 5. Performance measurement using the Carhart (1997) 4-Factor Model

\begin{tabular}{|c|c|c|c|c|c|c|c|}
\hline & Obs & $\alpha$ & RMRF & SMB & $\bar{H} H M L$ & $\bar{W} W M L$ & $\overline{R^{2}}$ \\
\hline AMP Aggressive & 67 & $\begin{array}{r}-0.381 * \\
(-1.78)\end{array}$ & $\begin{array}{r}0.635 * * * \\
(9.47)\end{array}$ & $\begin{array}{l}-0.119 \\
(-1.10)\end{array}$ & $\begin{array}{r}-0.408 * * * \\
(-3.73)\end{array}$ & $\begin{array}{l}0.001 \\
(0.01)\end{array}$ & $67.23 \%$ \\
\hline AMP Growth & 67 & $\begin{array}{r}-0.302 * \\
(-1.65)\end{array}$ & $\begin{array}{r}0.538 * * * \\
(9.65)\end{array}$ & $\begin{array}{l}-0.099 \\
(-1.08)\end{array}$ & $\begin{array}{r}-0.333 * * * \\
(-3.58)\end{array}$ & $\begin{array}{l}0.000 \\
(0.01)\end{array}$ & $66.82 \%$ \\
\hline AON Growth & 67 & $\begin{array}{l}-0.136 \\
(-0.59)\end{array}$ & $\begin{array}{r}0.596 * * * \\
(8.41)\end{array}$ & $\begin{array}{l}-0.107 \\
(-0.90)\end{array}$ & $\begin{array}{r}-0.343 * * * \\
(-2.87)\end{array}$ & $\begin{array}{l}-0.100 \\
(-1.16)\end{array}$ & $68.99 \%$ \\
\hline ASB & 67 & $\begin{array}{r}-0.249^{*} \\
(-1.96)\end{array}$ & $\begin{array}{r}0.719 * * * \\
(22.03)\end{array}$ & $\begin{array}{r}-0.205^{* * * *} \\
(-3.87)\end{array}$ & $\begin{array}{l}-0.067 \\
(-1.27)\end{array}$ & $\begin{array}{r}-0.050 \\
(-1.58)\end{array}$ & $90.76 \%$ \\
\hline Bro & 67 & $\begin{array}{r}0.083 \\
(0.39)\end{array}$ & $\begin{array}{r}0.512 * * * \\
(4.85)\end{array}$ & $\begin{array}{l}-0.171 \\
(-1.43)\end{array}$ & $\begin{array}{r}0.079 \\
(0.64)\end{array}$ & $\begin{array}{l}-0.009 \\
(-0.17)\end{array}$ & $65.69 \%$ \\
\hline Westpac Growth & 67 & $\begin{array}{l}-0.106 \\
(-0.78)\end{array}$ & $\begin{array}{r}0.557 * * * \\
(17.59)\end{array}$ & $\begin{array}{r}-0.115^{* *} \\
(-2.59)\end{array}$ & $\begin{array}{r}-0.074 * \\
(-1.70)\end{array}$ & $\begin{array}{l}-0.007 \\
(-0.24)\end{array}$ & $85.16 \%$ \\
\hline Fide & 67 & $\begin{array}{l}-0.074 \\
(-0.63)\end{array}$ & $\begin{array}{r}0.579 * * * \\
(8.90)\end{array}$ & $\begin{array}{r}-0.115^{* *} \\
(-2.05)\end{array}$ & $\begin{array}{r}0.061 \\
(1.04)\end{array}$ & $\begin{array}{r}-0.087 * * * \\
(-3.30)\end{array}$ & $85.51 \%$ \\
\hline & 67 & $\begin{array}{l}-0.144 \\
(-0.90)\end{array}$ & $\begin{array}{r}0.759 * * * \\
(15.30)\end{array}$ & $\begin{array}{l}-0.102 \\
(-1.45)\end{array}$ & $\begin{array}{l}-0.075 \\
(-1.44)\end{array}$ & $\begin{array}{r}-0.063^{* *} \\
(-2.22)\end{array}$ & $82.74 \%$ \\
\hline ish & 67 & $\begin{array}{l}-0.023 \\
(-0.10)\end{array}$ & $\begin{array}{r}0.746^{* * * *} \\
(9.28)\end{array}$ & $\begin{array}{r}0.275 * * * \\
(3.45)\end{array}$ & $\begin{array}{r}-0.326 * * * \\
(-3.02)\end{array}$ & $\begin{array}{r}-0.219 * * * \\
(-6.98)\end{array}$ & $81.33 \%$ \\
\hline For & 58 & $\begin{array}{r}-0.327 * \\
(-1.71)\end{array}$ & $\begin{array}{r}0.537 * * * \\
(7.16)\end{array}$ & $\begin{array}{l}-0.021 \\
(-0.24)\end{array}$ & $\begin{array}{r}-0.227^{*} \\
(-1.83)\end{array}$ & $\begin{array}{l}-0.030 \\
(-0.72)\end{array}$ & $74.47 \%$ \\
\hline rosvenor $\mathrm{F}$ & 67 & $\begin{array}{r}-0.412 * * * \\
(-3.92)\end{array}$ & $\begin{array}{r}0.812 * * * \\
\quad(16.50)\end{array}$ & $\begin{array}{r}-0.187 * \\
(-1.93)\end{array}$ & $\begin{array}{l}-0.013 \\
(-0.17)\end{array}$ & $\begin{array}{r}-0.061 * * * \\
(-2.15)\end{array}$ & $91.43 \%$ \\
\hline Merc & 67 & $\begin{array}{r}-0.330^{*} \\
(-1.78)\end{array}$ & $\begin{array}{r}0.683 * * * \\
(12.54)\end{array}$ & $\begin{array}{r}-0.167 * * \\
(-2.18)\end{array}$ & $\begin{array}{r}-0.196 * * \\
(-2.36)\end{array}$ & $\begin{array}{r}-0.113 * * * \\
(-2.04)\end{array}$ & $85.38 \%$ \\
\hline OneP & 67 & $\begin{array}{l}-0.194 \\
(-1.26)\end{array}$ & $\begin{array}{r}0.616^{* * *} * \\
(13.28)\end{array}$ & $\begin{array}{r}-0.211 * * * \\
(-3.70)\end{array}$ & $\begin{array}{l}-0.080 \\
(-1.32)\end{array}$ & $\begin{array}{l}-0.014 \\
(-0.32)\end{array}$ & $84.30 \%$ \\
\hline 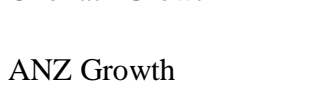 & 67 & $\begin{array}{l}-0.106 \\
(-0.63)\end{array}$ & $\begin{array}{r}0.672 * * * \\
\quad(17.18)\end{array}$ & $\begin{array}{r}-0.192 * * * \\
(-3.32)\end{array}$ & $\begin{array}{r}-0.098 * \\
(-1.88)\end{array}$ & $\begin{array}{l}-0.029 \\
(-0.58)\end{array}$ & $86.27 \%$ \\
\hline - Uiowtia & 67 & $\begin{array}{l}-0.090 \\
(-0.55)\end{array}$ & $\begin{array}{r}0.670 * * * \\
(17.19)\end{array}$ & $\begin{array}{r}-0.195 * * * \\
(-3.38)\end{array}$ & $\begin{array}{r}-0.094^{*} \\
(-1.81)\end{array}$ & $\begin{array}{l}-0.029 \\
(-0.58)\end{array}$ & $86.19 \%$ \\
\hline (1) & 67 & $\begin{array}{r}-0.478^{*} \\
(-1.72)\end{array}$ & $\begin{array}{r}0.791 * * * \\
\quad(14.12)\end{array}$ & $\begin{array}{r}-0.406^{* * * *} \\
(-3.36)\end{array}$ & $\begin{array}{l}-0.096 \\
(-0.92)\end{array}$ & $\begin{array}{c}-0.054 \\
(-0.77)\end{array}$ & $72.56 \%$ \\
\hline Staples Rodway Growth & 66 & $\begin{array}{l}-0.047 \\
(-0.27)\end{array}$ & $\begin{array}{r}0.490 * * * \\
(5.65)\end{array}$ & $\begin{array}{l}-0.028 \\
(-0.22)\end{array}$ & $\begin{array}{l}-0.161 \\
(-1.07)\end{array}$ & $\begin{array}{l}-0.056 \\
(-0.90)\end{array}$ & $62.68 \%$ \\
\hline TO & 67 & $\begin{array}{l}-0.222 \\
(-1.35)\end{array}$ & $\begin{array}{r}0.678 * * * \\
(15.03)\end{array}$ & $\begin{array}{l}-0.068 \\
(-1.11)\end{array}$ & $\begin{array}{r}-0.234 * * * \\
(-3.39)\end{array}$ & $\begin{array}{l}-0.061 \\
(-1.37)\end{array}$ & $85.54 \%$ \\
\hline TOWER Equity & 67 & $\begin{array}{r}-0.500 * * \\
(-2.68)\end{array}$ & $\begin{array}{r}1.005^{* * *} * \\
(20.92)\end{array}$ & $\begin{array}{l}-0.103 \\
(-1.24)\end{array}$ & $\begin{array}{r}-0.386 * * * \\
(-4.44)\end{array}$ & $\begin{array}{l}-0.051 \\
(-1.00)\end{array}$ & $88.32 \%$ \\
\hline
\end{tabular}

This table reports regression results for Equation (6), where the CAPM is augmented with the global $S M B, H M L$ and $W M L$ factors from Kenneth French's website. Obs. is the number of observations, $\alpha$ measures the risk-adjusted performance relative to the benchmark, $R M R F$ is the excess return on the global market portfolio, $S M B$ is the global size factor, $H M L$ is the global value factor, $W M L$ is the global momentum factors and $R^{2}$ measures the goodness of fit. Newey-West corrected t-statistics are reported in parentheses and *,**, and $* * *$ indicate significance at the $10 \%, 5 \%$, and $1 \%$ levels, respectively. 
Table 6. Market Timing Skills

\begin{tabular}{|c|c|c|c|c|c|}
\hline & Obs & $\alpha$ & RMRF & RMRR ${ }^{2}$ & $R^{2}$ \\
\hline AMP Aggressive & 67 & $\begin{array}{l}0.066 \\
(0.15)\end{array}$ & $\begin{array}{r}0.510 * * * \\
(4.73)\end{array}$ & $\begin{array}{r}-0.026 * * * \\
(-2.64)\end{array}$ & $28.18 \%$ \\
\hline AMP Growth & 67 & $\begin{array}{l}0.062 \\
(0.18)\end{array}$ & $\begin{array}{r}0.435 * * * \\
(4.90)\end{array}$ & $\begin{array}{r}-0.021 * * \\
(-2.57)\end{array}$ & $29.14 \%$ \\
\hline AON Growth & 67 & $\begin{array}{l}0.129 \\
(0.27)\end{array}$ & $\begin{array}{r}0.505 * * * \\
(4.64)\end{array}$ & $\begin{array}{l}-0.015 \\
(-1.45)\end{array}$ & $23.56 \%$ \\
\hline ASB Growth & 67 & $\begin{array}{l}-0.125 \\
(-0.51)\end{array}$ & $\begin{array}{r}0.681 * * * \\
(9.91)\end{array}$ & $\begin{array}{l}-0.007 \\
(-0.84)\end{array}$ & $66.02 \%$ \\
\hline Brook Growth & 67 & $\begin{array}{l}-0.079 \\
(-0.36)\end{array}$ & $\begin{array}{r}0.509 * * * \\
(5.71)\end{array}$ & $\begin{array}{l}0.011 \\
(0.66)\end{array}$ & $61.19 \%$ \\
\hline Westpac Growth & 67 & $\begin{array}{r}0.019 \\
(0.09)\end{array}$ & $\begin{array}{r}0.523 * * * \\
\quad(12.57)\end{array}$ & $\begin{array}{l}-0.007 \\
(-1.50)\end{array}$ & $70.62 \%$ \\
\hline Fidelity Growth & 67 & $\begin{array}{l}-0.245 \\
(-1.52)\end{array}$ & $\begin{array}{r}0.591 * * * \\
(9.87)\end{array}$ & $\begin{array}{c}0.011 \\
(1.08)\end{array}$ & $74.29 \%$ \\
\hline Fidelity Aggressive & 67 & $\begin{array}{l}-0.221 \\
(-0.88)\end{array}$ & $\begin{array}{r}0.733 * * * \\
\quad(11.38)\end{array}$ & $\begin{array}{l}0.006 \\
(0.93)\end{array}$ & $69.33 \%$ \\
\hline Fisher Growth & 67 & $\begin{array}{l}-0.135 \\
(-0.40)\end{array}$ & $\begin{array}{r}0.726 * * * \\
(6.18)\end{array}$ & $\begin{array}{l}0.009 \\
(0.50)\end{array}$ & $55.85 \%$ \\
\hline Forsyth Barr Growth & 58 & $\begin{array}{l}-0.131 \\
(-0.49)\end{array}$ & $\begin{array}{r}0.470 * * * \\
(4.69)\end{array}$ & $\begin{array}{l}-0.010 \\
(-0.91)\end{array}$ & $44.34 \%$ \\
\hline Grosvenor High Growth & 67 & $\begin{array}{l}-0.251 \\
(-1.45)\end{array}$ & $\begin{array}{r}0.794 * * * \\
\quad(11.62)\end{array}$ & $\begin{array}{l}-0.011 \\
(-1.06)\end{array}$ & $76.49 \%$ \\
\hline Mercer High Growth & 67 & $\begin{array}{l}-0.097 \\
(-0.26)\end{array}$ & $\begin{array}{r}0.626 * * * \\
(6.05)\end{array}$ & $\begin{array}{l}-0.014 \\
(-1.17)\end{array}$ & $42.80 \%$ \\
\hline OnePath Growth & 67 & $\begin{array}{r}0.132 \\
(0.48)\end{array}$ & $\begin{array}{r}0.626 * * * \\
(10.10)\end{array}$ & $\begin{array}{r}-0.015 * * \\
(-2.19)\end{array}$ & $62.24 \%$ \\
\hline ANZ Growth & 67 & $\begin{array}{l}0.145 \\
(0.53)\end{array}$ & $\begin{array}{r}0.624 * * * \\
(10.13)\end{array}$ & $\begin{array}{r}-0.015 * * \\
(-2.20)\end{array}$ & $62.00 \%$ \\
\hline SIL Growth & 67 & $\begin{array}{l}-0.284 \\
(-0.54)\end{array}$ & $\begin{array}{r}0.719 * * * \\
(5.82)\end{array}$ & $\begin{array}{l}-0.011 \\
(-0.90)\end{array}$ & $36.85 \%$ \\
\hline Smart Growth & 66 & $\begin{array}{l}-0.041 \\
(-0.15)\end{array}$ & $\begin{array}{r}0.449 \\
(5.55)\end{array}$ & $\begin{array}{l}0.000 \\
(0.04)\end{array}$ & $41.29 \%$ \\
\hline Staples Rodway Growth & 67 & $\begin{array}{r}0.045 \\
(0.16)\end{array}$ & $\begin{array}{l}0.617 \\
(8.00)\end{array}$ & $\begin{array}{r}-0.016^{*} \\
(-1.81)\end{array}$ & $55.40 \%$ \\
\hline TOWER Growth & 67 & $\begin{array}{l}-0.115 \\
(-0.35)\end{array}$ & $\begin{array}{r}0.896 \\
(8.27)\end{array}$ & $\begin{array}{r}-0.022^{*} \\
(-1.84)\end{array}$ & $57.25 \%$ \\
\hline
\end{tabular}

This table reports regression results for the market timing model in Equation (7). The benchmark $(R M R F)$ is the global market portfolio obtained from Kenneth French's website. Obs. is the number of observations, $R M R F$ is the excess return on the global market portfolio, $R M R F^{2}$ measures market timing skills and $R^{2}$ measures the goodness of fit. Newey-West corrected t-statistics are reported in parentheses and $* * *$, and $* * *$ indicate significance at the $10 \%, 5 \%$, and $1 \%$ levels, respectively. 
Figure 1

Panel A - Replication of the Aon Balanced fund

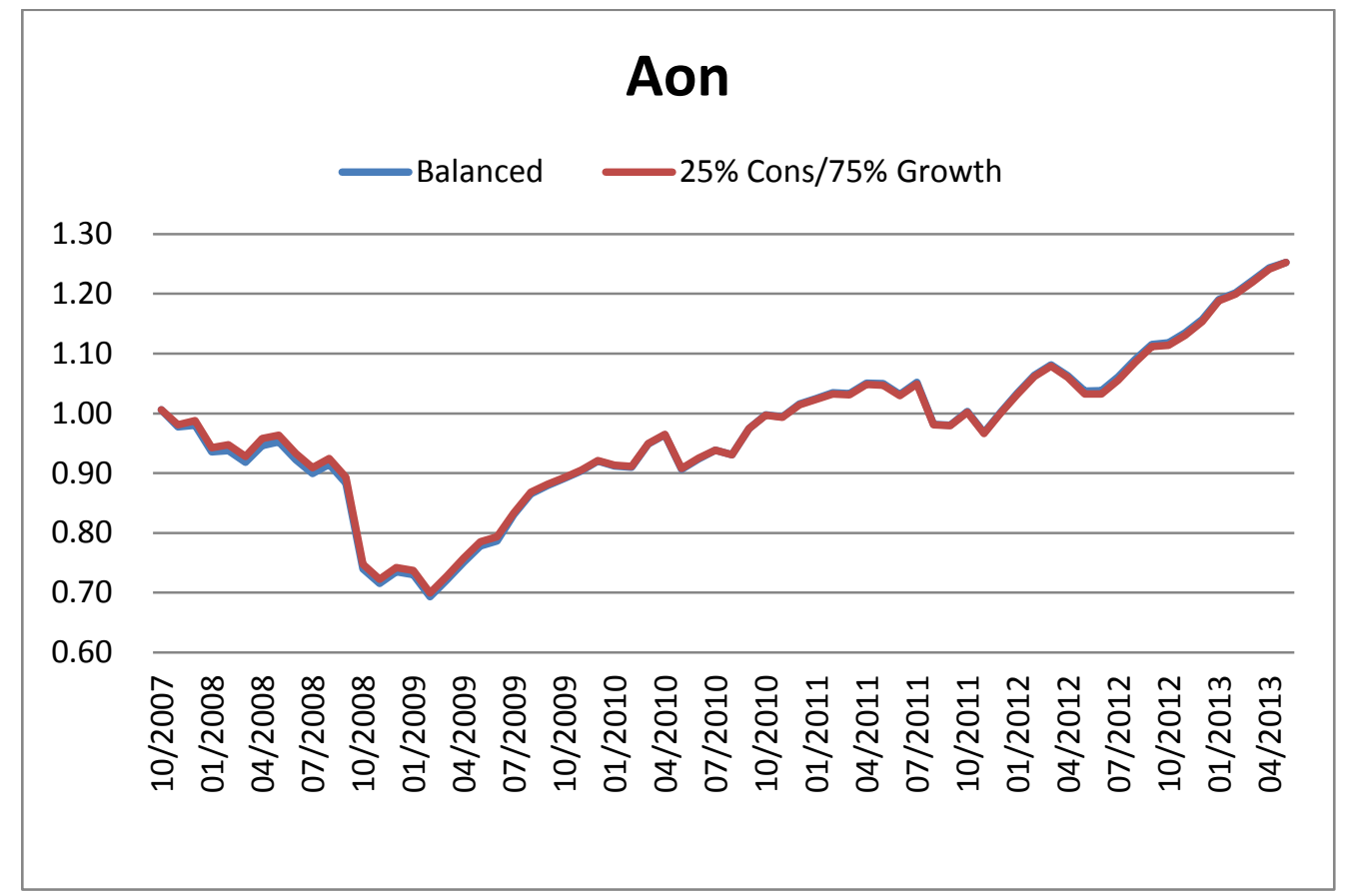

Panel B-Replication of the AMP Moderate Balanced fund

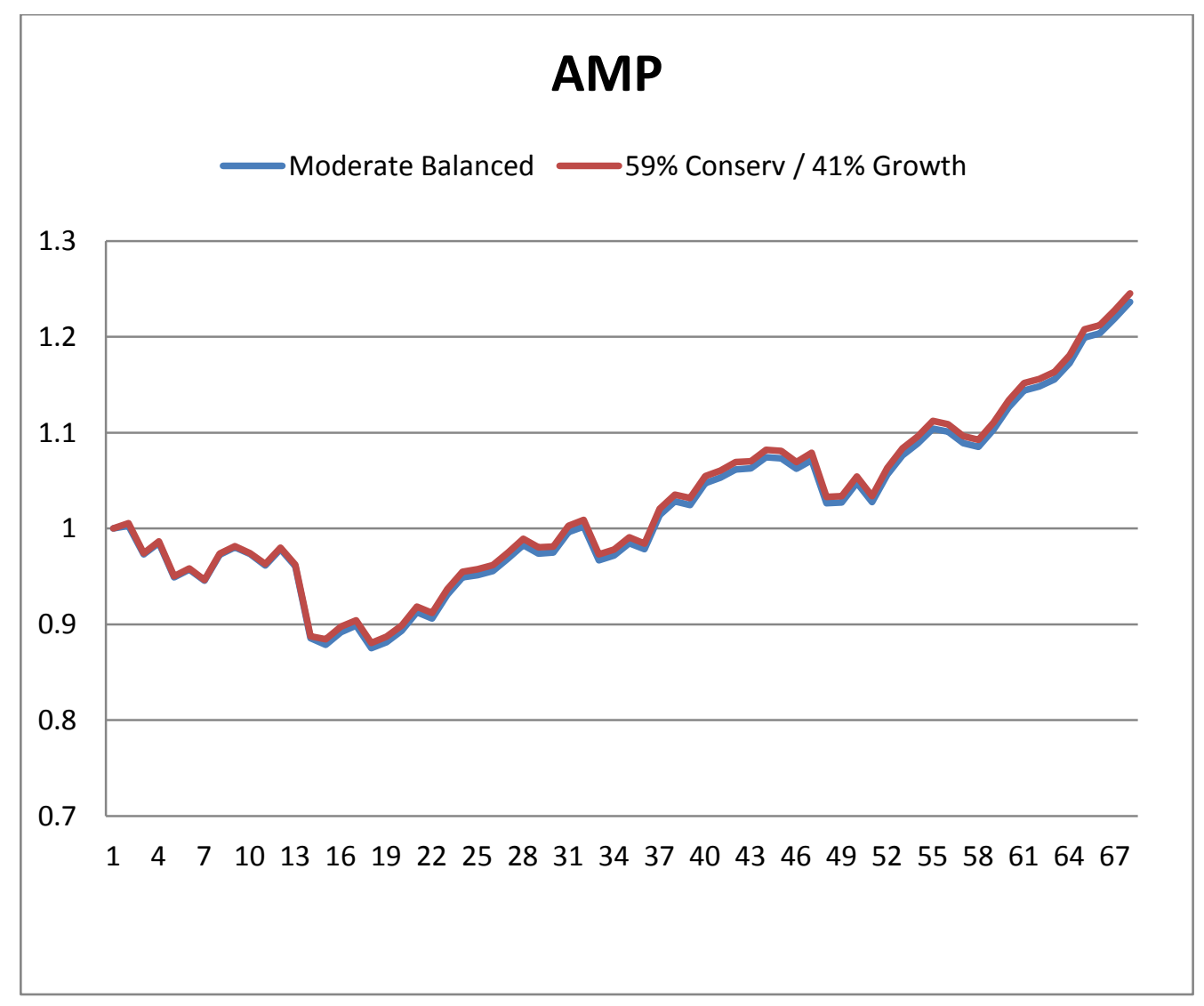

